\title{
SciBX
}

THE DISTILLERY

\section{Science-Business eXchange}

\section{This week in techniques}

$\begin{array}{ll}\begin{array}{l}\text { Approach } \\ \text { Imaging }\end{array} & \text { Summary } \\ \begin{array}{l}\text { Near-infrared fluorescent } \\ \text { (NIRF) molecule-labeled }\end{array} & \begin{array}{l}\text { A study in mice identified NIRF molecule-labeled chlorotoxin analogs that } \\ \text { chlorotoxin analogs for }\end{array} \\ \begin{array}{l}\text { injection image brain tumors. In mice with advanced brain tumors, tail vein } \\ \text { in tumor imaging }\end{array} & \begin{array}{l}\text { in selective illumination of medulloblastoma cancer tissue compared with that } \\ \text { of normal brain tissue. Next steps could include evaluating the chlorotoxin } \\ \text { analogs in imaging studies of additional tumor types. }\end{array}\end{array}$

SciBX 4(5); doi:10.1038/scibx.2011.148

Published online Feb. 3, 2011

\section{Publication and contact}

Licensing status information

Patent and licensing Akcan, M. et al. J. Med. Chem.; status unavailable published online Jan. 6, 2011; doi:10.1021/jm101018r Contact: James M. Olson, Fred Hutchinson Cancer Research Center, Seattle, Wash. e-mail:

jolson@fhcrc.org 